UDC 57.022, 57.023

doi: https://doi.org/10.15407/ubj93.05.090

\title{
DIETARY PROTEIN DEFINES STRESS RESISTANCE, OXIDATIVE DAMAGES AND ANTIOXIDANT DEFENSE SYSTEM IN DROSOPHILA MELANOGASTER
}

\author{
O. STRILBYTSKA ${ }^{1 \bowtie}$, A. ZAYACHKIVSKA ${ }^{1}$, T. STRUTYNSKA ${ }^{1}$, \\ U. SEMANIUK ${ }^{1}$, A. VAISERMAN ${ }^{2}$, O. LUSHCHAK ${ }^{1,3 \bowtie ~}$ \\ ${ }^{1}$ Vasyl Stefanyk Precarpathian National University, \\ Department of Biochemistry and Biotechnology, Ivano-Frankivsk, Ukraine; \\ ${ }^{2}$ D.F. Chebotarev Institute of Gerontology, NAMS, Kyiv, Ukraine; \\ ${ }^{3}$ Research and Development Institute, Ivano-Frankivsk, Ukraine; \\ 凶e-mail: olya_b08@ukr.net or oleh.lushchak@pnu.edu.ua
}

Received: 06 April 2021; Accepted: 22 September 2021

\begin{abstract}
Dietary interventions have been previously shown to influence lifespan in diverse model organisms. Manipulations with macronutrients content including protein and amino acids have a significant impact on various fitness and behavioral traits in the fruit fly Drosophila melanogaster. Therefore, we asked if yeast amount of the diet could influence stress resistance and antioxidant defense system in Drosophila. We examined the effects of four diets differing in the relative level of yeast, as a source of protein, on resistance to cold, heat, starvation and oxidative stress induced by menadione as well as activities of antioxidant enzymes and levels of oxidative stress markers. Protein restriction as well protein-enriched diet led to a reduction of survival under starvation and oxidative stress conditions. However, enhanced resistance to heat shock was affected by high yeast concentration in the diet. Also, protein-rich diets resulted in higher activity of antioxidant enzymes. Increased levels of protein thiols, low-molecule mass thiols, lipid peroxides in response to high yeast concentration in the diet were detected in females only. Thus, we can assume that consumption of a high protein diet could induce oxidative stress in fruit fly.
\end{abstract}

Key wo rds: nutrition, diet, oxidative stress, metabolism, fruit fly.

$\mathrm{A}$ ll organisms adapt and respond to the source of nutrients available from the environment. Metabolism, growth, and longevity directly depend on dietary conditions. The fruit fly Drosophila melanogaster has been extensively used to study organismal response to different dietary variations. Macronutrient balance, as well as quantity and quality of specific nutrients, are important determinants of various traits in Drosophila $[1,2]$. The state-space modeling platform, such as the Geometric Framework (GF) was suggested to provide requirements of Drosophila organism for multiple nutrients, the values of foods in relation to these requirements [3].

The main macromolecules in food are proteins, lipids, and carbohydrates. However, consumption of nutritional components, which exceed the energy needs, could result in obesity [4, 5]. Dietary yeast provides essential nutrients for Drosophila survival such as amino acids, sterols, vitamins, and fatty acids [6, 7]. Lowering yeast concentration in the diet has been shown to prolong lifespan in D. melanogaster [8]. Moreover, consumption of a diet with high protein-to-carbohydrate level leads to lifespan shortening and suggested about the harmful effect of protein overconsumption [1]. Studies performed in rodents showed increased survival of rats and mice under protein restriction $[9,10]$. However, the molecular mechanisms responsible are unknown.

According to the mitochondrial free radical theory of aging, the generation of reactive oxygen species (ROS) can be one of the main factors that determine the aging rate. ROS are usually produced in the mitochondria. Balance between ROS overpro- 
duction and disposal is important for maintaining healthy redox processes within the cells [11]. Cellular defense systems are important to minimize the detrimental effects of high ROS production as well as help to control oxidative stress [12]. Numerous studies have documented the decrease in ROS generation and oxidative damage under calorie restriction (CR) conditions. However, how decreased nutrients intake causes these beneficial changes is still unclear. The mechanisms underlying the role of diet in the regulation of aging have been widely studied. Indeed, target of rapamycin (mTOR) pathway suggested to be a regulator of physiological and metabolic traits in response to nutrient availability $[13,14]$. Reduced protein intake also appears to extend lifespan by affecting the insulin/IGF-1 or TOR signaling pathways $[13,15]$.

Here, we present a study in Drosophila aimed to understand how dietary protein as a considerable nutritional signal regulates functional senescence. Since the diet is a key regulator of metabolic processes that are relevant to oxidative stress responses, we hypothesized that protein content in the food therefore could affect stress resistance and antioxidant defense system of $D$. melanogaster. In the present study, we completed an assessment of the impact of dietary yeast on resistance to various stresses (cold, heat, starvation, menadione exposure) and oxidative stress markers (antioxidant enzyme activities and the levels of carbonyl protein, lipid peroxides, thiols). We hypothesized that the content of yeast in the diet, the main source of proteins and amino acids, from adult food would be associated with deep physiological alterations which may be caused by a shift in cellular redox processes. The primary role of nutrient-sensing signaling pathways was proposed to link redox homeostasis with nutritional conditions.

\section{Materials and Methods}

Insects, maintaining and conditions. We used Canton-S [D. melanogaster Meigen] flies received from the Bloomington Stock Center (Indiana University, USA). All flies were grown on a medium that containing $4 \%$ sucrose, $4 \%$ dry yeast, $1.2 \%$ agar and $0.18 \%$ nipagin as an anti-fungal agent. Flies were reared at $25^{\circ} \mathrm{C}$ and relative humidity of $60-70 \%$ on a $12 \mathrm{~h}$ day/night cycle. Flies aged four days were separated by sex and kept on the above-mentioned medium for one more day for recovery after $\mathrm{CO}_{2}$ anesthesia. Then male and female flies were placed separately at standard densities of 200 flies per 1.51 demographic cages. Cages were supplemented with $25 \mathrm{ml}$ plastic vial filled with the $5 \mathrm{ml}$ of experimental medium, containing $4 \%$ of sucrose and different concentrations of dry yeasts: $0.25,4,10,15 \%, 1.2 \%$ of agar, $0.18 \%$ of nipagin. On the 25 -th day of the experiment, flies were used for physiological tests or frozen in liquid nitrogen for biochemical measurements.

Resistance to starvation and oxidative stress. Resistance to starvation was measured by feeding experimental flies with $0.5 \%$ agarose medium. Sensitivity to oxidative stress was assessed by adding $20 \mathrm{mM}$ menadione, an inducer of oxidative stress [16], into a 5\% sucrose solution. For all treatments, 15 flies were placed into $15 \mathrm{ml}$ vial with $3 \mathrm{ml}$ of medium. The vials were changed every other day and dead flies were removed. Fly viability was checked daily at $9 \mathrm{am}, 3 \mathrm{pm}$ and $9 \mathrm{pm}$.

Heat shock sensitivity and recovery. 25-days old flies that were previously fed by diets with different dry yeast concentrations were subjected to heat and cold shock. Flies were placed into individual test tubes and heat shock was induced by placing the tube with a fly into a water bath set to $43^{\circ} \mathrm{C}$ [17]. Full immobility was referred to as heat-induced paralysis, and the time was scored. Then, flies were removed from the water bath and kept at room temperature $\left(21-23^{\circ} \mathrm{C}\right)$ until full recovery of locomotion. About 8-10 flies were tested for each experimental cohort. Resistance to cold was determined through exposure flies to nonfreezing temperature $\left(0^{\circ} \mathrm{C}\right)$, which caused cold coma usually referred to as "chill coma recovery" [18]. About 10 flies of each experimental cohort were placed in the glass vials, which were put on ice in the isolated boxes $\left(0^{\circ} \mathrm{C}\right)$ for $1 \mathrm{~min}$. Then, motionless flies were transferred into Petri dishes at room temperature $\left(21-23^{\circ} \mathrm{C}\right)$, and the time of recovery was recorded.

Enzymatic activities. Flies were homogenized using a Potter-Elvejhem glass homogenizer in cold $50 \mathrm{mM}$ potassium phosphate buffer, $\mathrm{pH} 7.5$, containing $0.5 \mathrm{mM}$ EDTA and $1 \mathrm{mM}$ PMSF (1:10 $\mathrm{w}: \mathrm{v})$. Centrifugation was performed at $16000 \mathrm{~g}$ for

\footnotetext{
Abbreviations: SOD, superoxide dismutase; ROS, reactive oxygen species; GST, glutathione-S-transferase; G6PDH, glucose-6-phosphate dehydrogenase; IDH, isocitrate dehydrogenase.
} 
15 min at $4^{\circ} \mathrm{C}$ in an Eppendorf 5415R centrifuge (Germany). The supernatants were collected and used for the determination of enzymatic activities.

The activities of superoxide dismutase (SOD, EC 1.15.1.1) and catalase (EC 1.11.1.6) were measured as described previously [19]. Briefly, SOD activity was assayed at $406 \mathrm{~nm}$ by inhibition of quercetin oxidation by superoxide anion. One unit of SOD activity was defined as the amount of supernatant protein that inhibited the rate of quercetin oxidation by $50 \%$. Catalase activity was registered by the rate of hydrogen peroxide decomposition at $240 \mathrm{~nm}$. Enzyme activity was calculated using the extinction coefficient for hydrogen peroxide $39.4 \mathrm{M}^{-1} \mathrm{~cm}^{-1}$.

Total activity of glutathione-S-transferase (GST, EC 2.5.1.18) was determined by measuring changes in absorbance of the conjugate formed between 1-chloro-2,4-dinitrobenzene and glutathione detected at $340 \mathrm{~nm}$ using molar absorption coefficient $9600 \mathrm{M}^{-1} \mathrm{~cm}^{-1}$. The activities of glucose6-phosphate dehydrogenase (G6PDH, EC 1.1.1.49) and isocitrate dehydrogenase (IDH, EC 1.1.1.49) were determined at $340 \mathrm{~nm}$ by the rate of formation of NADPH [20]. To calculate enzyme activities, an absorption coefficient for NADPH $6220 \mathrm{M}^{-1} \mathrm{~cm}^{-1}$ was used. One unit of GST, G6PDH, and IDH activity is defined as the amount of enzyme that consumes $1 \mu \mathrm{mol}$ of substrate or generates $1 \mu \mathrm{mol}$ of product per minute. Activities are expressed as international units (or milliunits) per protein milligram.

Oxidative stress markers. For making supernatants flies were separated by sex, weighted and homogenized ( $1: 10 \mathrm{w} / \mathrm{v})$ with Potter-Elvjeham glass homogenizer with adding $50 \mathrm{mM}$ potassium phosphate buffer, $\mathrm{pH} 7.5$, containing $0.5 \mathrm{mM}$ EDTA and $1 \mathrm{mM}$ PMSF. Samples were centrifuged for $15 \mathrm{~min}$ at $13000 \mathrm{~g}$ (Eppendorf 5415R) [17] and supernatants were used for the subsequent measurement. The level of carbonyl proteins (CP) was detected by reaction with 2,4-dinitrophenylhydrazine as described previously [21]. The resulting 2,4-dinitrophenylhydrazones were quantified spectrophotometrically. Protein carbonyl content was calculated using the absorbance coefficient $22 \mathrm{mM}^{-1} \mathrm{~cm}^{-1}$ for 2,4-dinitrophenylhydrazone measured at $370 \mathrm{~nm}$. The content of carbonyl proteins was expressed in nanomoles per milligram of protein [17]. Lipid peroxide $(\mathrm{LOOH})$ content was assayed with xylenol orange [22]. Experimental flies were homogenized with 10 volumes of $96 \%$ ice-cold ethanol, centrifuged for $5 \mathrm{~min}$ at 13,000 g. Resulted supernatants were used for the assay. The content of $\mathrm{LOOH}$ was expressed as na- nomoles of cumene hydroperoxide equivalents per gram of fly weight. The content of free thiol groups was evaluated by Ellman's method using DTNB [17]. The content of protein thiols groups was calculated as the difference between protein thiols (P-SH) and low molecular mass thiols (L-SH). The content of the protein thiols was expressed in mmol per $1 \mathrm{mg}$ of protein and low molecular weight per mg of wet weight.

Statistical analysis and graphical representation. Experimental data are presented as mean \pm SEM and $P<0.05$ is considered as significantly different. Statistical analysis was performed using "Prism” (GraphPad Software, Inc.). Tukey's multiply comparison test has been used to compare heat shock in, heat shock out, cold shock, SOD and catalase activity, GST, G6PDH, IGH, P-SH, L-SH, protein carbonyl, LOOH concentration. A two-way analysis of variance (ANOVA) was conducted to compare the parameters at two factors: diet (with different yeast content) and sex (males vs. females). Log-rank test was used to analyze survival curves. All graphs were generated in "GraphpadPrism7”.

\section{Results}

Resistance to starvation and oxidative stress. In order to understand how protein concentration in the diet might impact stress resistance in Drosophila, we analyzed fly survival under starvation and oxidative stress. Higher resistance to starvation was detected in females that consumed diet with $4 \%$ (log-rank test, $P=0.0430 ; \chi^{2}=4.096$ ) and 10\% (logrank test, $P=0.0377 ; \chi^{2}=4,32$ ) of yeast as compared to those fed 15\% (Fig. 1, A). Protein-restricted diet ( $0.25 \%$ of yeast) led to shorter survival in females at starvation as compared to all other diets (log-rank test, 4\%Y: $P<0.0001, \chi^{2}=28.08$; $10 \% \mathrm{Y}: P<0.0001$, $\chi^{2}=30 ; 15 \% \mathrm{Y}: P=0.0002, \chi^{2}=4.12$ ).

We observed higher survival under oxidative stress induced by menadione in males that consumed medium with $10 \%$ of yeast as compared to $4 \%$ (logrank test, $P=0.0151 ; \chi^{2}=5.909$ ) and $15 \%$ (log-rank test, $P=0.0013 ; \chi^{2}=4.3$ ) (Fig. $1, B$ ). Consumption of food with $0.25 \% \mathrm{Y}$ decreased survival of males as compared to all others cohorts (log-rank test, 4\%Y: $P=0.0274, \chi^{2}=4.87 ; 10 \% Y: P<0,0001, \chi^{2}=28.39$; $\left.15 \% \mathrm{Y}: P=0.0016, \chi^{2}=9.98\right)$. We observed extended survival in females fed diet with $4 \%$ of yeast as compared to $0.25 \%$ (log-rank test, $P=0.0069 ; \chi^{2}=$ 7.301) and $15 \%$ (log-rank test, $\left.P=0.0395 ; \chi^{2}=4.24\right)$ (Fig. 1, B). 
A

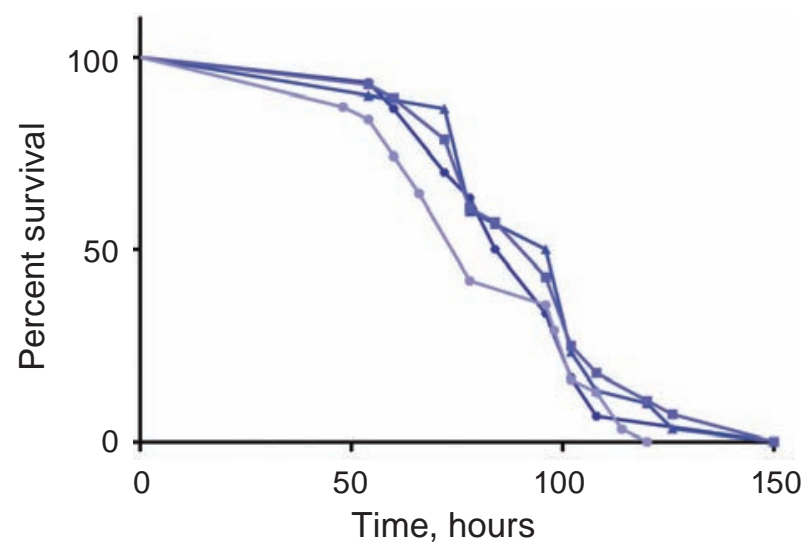

C

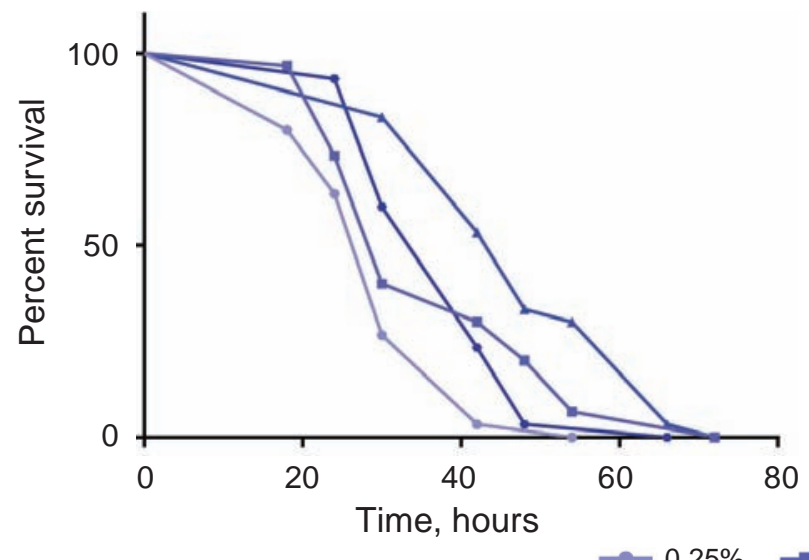

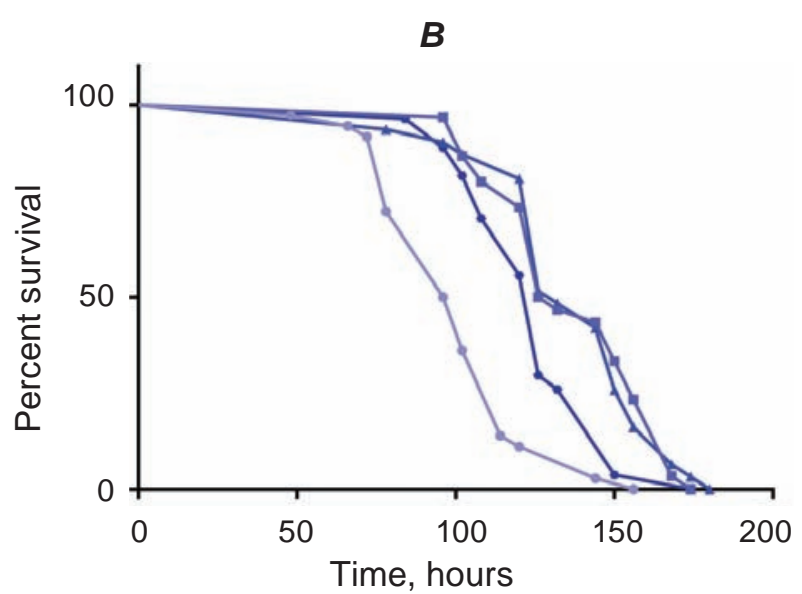

D

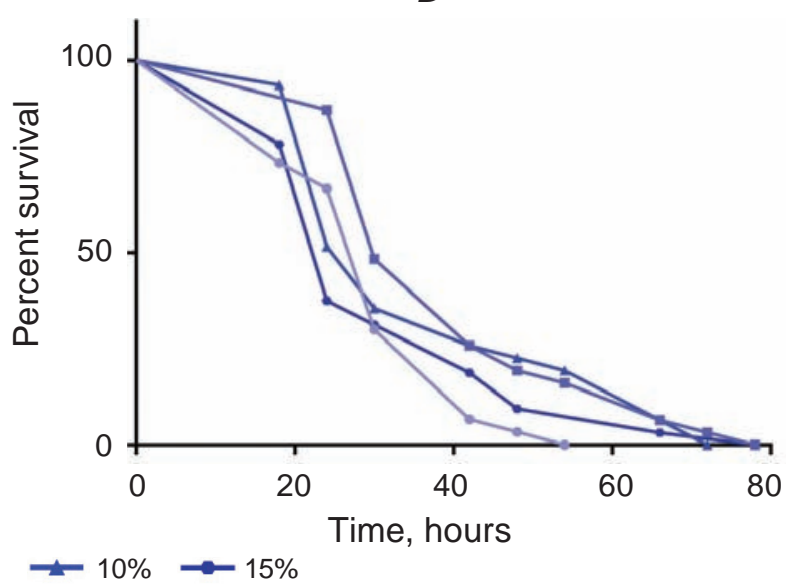

Fig. 1. Resistance to starvation ( $\boldsymbol{A}$ - males; $\boldsymbol{B}$-females) and oxidative stress ( $\boldsymbol{C}$ - males; $\boldsymbol{D}$ - females). Survival curves for the experimental flies fed on diets with different yeast content $(0.25,4,10$, and 15\%) and constant concentrations of sucrose (4\%). Each curve shows the fraction of individuals alive as a function of age with about 50 flies per group. Statistical analysis of differences in survival was conducted with a log-rank test

Heat and cold shock resistance. It is known that heat shock proteins (HSP) are synthesized in response to temperature changes. HSP plays an important role in physiological stress response and in the acquisition of stress tolerance [23]. We assumed that heat and cold shock resistance may depend on the protein concentration in the diet. Recovery time from heat stress in groups significantly depended on yeast concentration in the diet (Table; $\mathrm{F}_{3,16}=6.58$, $P=0.0042)$ and fly gender $\left(\mathrm{F}_{1,16}=19.2, P=0.0005\right)$. The recovery time was three and two times higher in male and female flies that consumed the diet with $0.25 \%$ of yeast as compared to all other experimental cohorts (Fig. 2, $B ; P<0.0001$ ). We found that yeast concentration in the diet had no impact on the time needed for Drosophila heat coma entrance (Fig. 2, A) as well as resistance to cold stress (Fig. 2, C).
First-line antioxidant enzymes activities. SOD activity depended on yeast concentration $\left(\mathrm{F}_{3,24}=9.86, P=0.0002\right)$ and fly gender $\left(\mathrm{F}_{1,24}=36.5\right.$, $P<0.0001$ ). We observed $30 \%$ higher SOD activity in males that consumed food with $15 \%$ of yeast as compared to $0.25 \%$ (Tukey's test, $P=0.0021$ ) and $4 \%$ of yeast (Fig. 3, $A$; Tukey's test, $P=0.0086$ ). Females fed by diet with $15 \%$ of yeast displayed $\sim 35 \%$ higher SOD activity as compared to $4 \%$ (Tukey's test, $P=0.0136$ ) and $10 \%$ of yeast (Fig. 3, $A$; Tukey's test, $P=0.0068)$. Catalase activity significantly depended on yeast concentration in the diet $\left(\mathrm{F}_{3,24}=10.2, P=0.0005\right)$, sex $\left(\mathrm{F}_{1,24}=89.9\right.$, $P<0.0001)$ and interaction between sex and diet $\left(\mathrm{F}_{3,24}=8.25, P=0.0015\right)$. We observed $\sim 30 \%$ lower catalase activity in males that consumed medium with $0.25 \%$ of yeast as compared to all other experi- 
Ta b le. Statistical analysis (two-way ANOVA followed by Tukey's honest significance test) of different indices presented in this study from Canton-S D. melanogaster flies fed by diet with different yeast concentrations

\begin{tabular}{l|c|c|c|c|c|c}
\hline \multirow{2}{*}{ Parameter } & \multicolumn{2}{|c|}{ Concentration, DF=3 } & \multicolumn{2}{c|}{ Sex, DF=1 } & \multicolumn{2}{c}{ Concentration*Sex, DF=3 } \\
\cline { 2 - 7 } & F ratio & $P$ & F ratio & $P$ & F ratio & $P$ \\
\hline Heat shock in & 6.58 & $0.0042^{*}$ & 19.2 & $0.0005^{*}$ & 0.818 & 0.5027 \\
Heat shock out & 53 & $<0.0001^{*}$ & 39.5 & $<0.0001^{*}$ & 0.232 & 0.8727 \\
Cold shock & 5.16 & $0.0110^{*}$ & 2.15 & 0.1618 & 2.67 & 0.0828 \\
SOD activity & 9.86 & $0.0002^{*}$ & 36.5 & $<0.0001^{*}$ & 2.44 & 0.0892 \\
Catalase activity & 10.2 & $0.0005^{*}$ & 89.9 & $<0.0001^{*}$ & 8.25 & $0.0015^{*}$ \\
GST & 16.5 & $<0.0001^{*}$ & 0.401 & 0.5325 & 1.52 & 0.2353 \\
G6PDH & 53.5 & $<0.0001^{*}$ & 205 & $<0.0001^{*}$ & 18.4 & $<0.0001^{*}$ \\
IGH & 14.3 & $<0.0001^{*}$ & 264 & $<0.0001^{*}$ & 7.63 & $0.0009^{*}$ \\
P-SH & 8.41 & $0.0014^{*}$ & 263 & $<0.0001^{*}$ & 4.91 & $0.0132^{*}$ \\
L-SH & 6.52 & $0.0043^{*}$ & 1.75 & 0.2044 & 4.9 & $0.0133^{*}$ \\
Protein carbonyl & 32.8 & $<0.0001^{*}$ & 73.1 & $<0.0001^{*}$ & 8.57 & $0.0013^{*}$ \\
LOOH & 9.14 & $0.0009^{*}$ & 363 & $<0.0001^{*}$ & 6.51 & $0.0044^{*}$ \\
\hline
\end{tabular}

*Significant difference

mental diets (Fig. 3, B; Tukey's test, $P<0.0004$ ). However, catalase activity in females was not affected by yeast concentration in the diet.

Second-line antioxidant enzymes activities. GST, G6PDH, and IDH indirectly help the cell to protect against ROS. They assist the first line antioxidants to combat ROS by supplying reductive equivalents such as GSH and NADPH or by eliminating oxidatively modified compounds. GST, G6PDH could contribute to GSH production, and IDH - to NADPH [11]. GST activity was associated with yeast concentration in the diet $\left(\mathrm{F}_{3,24}=16.5\right.$, $P<0.0001)$. Enzyme activity was significantly increased in males that consumed food with $15 \%$ of yeast as compared to all other groups (Fig. 4, A; Tukey's test, $P<0.0004$ ). Females fed with $15 \%$ of yeast displayed higher GST activity as compared to $0.25 \%$ and $4 \%$ of yeast (Fig. 4 , $A$; Tukey's test, $P<0.04$ ). G6PDH activity strongly depended on yeast concentration $\left(\mathrm{F}_{3,24}=53.5, P<0.0001\right)$, fly gender $\left(\mathrm{F}_{1,24}=205, P<0.0001\right)$, and their interaction $\left(\mathrm{F}_{3,24}\right.$ $=18.4, P<0.0001)$. We found, that G6PDH activity in males increased in the order $0.25<4<10$ and $15 \%$ (Fig. 4, $B$; Tukey's test, $P<0.0001$ ). Consumption of diet with 10 and $15 \%$ of yeast leads to higher G6PDH activity in males by $20 \%$ as compared to $4 \%$ of yeast (Fig. 4, B; Tukey's test, $P<0.02$ ), and by $65 \%$ as compared to $0.25 \%$ of yeast (Fig. $4, B$; Tukey's test, $P<0.0001)$. Hence, the lowest G6P-
$\mathrm{DH}$ activity was revealed in males that consumed a diet with $0.25 \%$ of yeast (Fig. $4, B$ ). G6PDH activity was higher in females that consumed a diet with 10 and $15 \%$ of yeast as compared to those fed diet with $0.25 \%$ yeast (Fig. $4, B$; Tukey's test, $P<0.03$ ). IDH activity in flies was determined by yeast concentration in the diet $\left(\mathrm{F}_{3.24}=14.3, P<0.0001\right)$, fly gender $\left(\mathrm{F}_{1,24}=264, P<0.0001\right)$ and interaction between these factors (F3,24 $=7.63, \mathrm{p}=0.0009)$. We found, that IDH activity in males increased in the order $0.25 \%<4 \%<15 \%$ Y (Fig. 4, C; Tukey's test, $P<0.0001)$. Consumption of diet with $15 \%$ yeast caused higher IDH activity in males as compared to $0.25 \%$ and $4 \%$ of yeast (Fig. $4, C$; Tukey's test, $P<0.009$ ). The activity of IDH in females was not affected by dietary protein.

Level of the oxidative stress markers. The level of protein thiols (-SH) in flies significantly depended on yeast concentration in the diet $\left(\mathrm{F}_{3,16}=8.41\right.$, $P=0.0014)$, fly gender $\left(\mathrm{F}_{1,16}=263, P<0.0001\right)$ and interaction between these two factors $\left(\mathrm{F}_{3,16}=4.91\right.$, $P=0.0132$ ). Females fed by diet with $0.25 \%$ of yeast had 30\% lower P-SH level as compared to all other experimental cohorts (Fig. 5, A; Tukey's test, $P<0.006)$. Yeast concentration in the diet did not affect the level of P-SH in males. L-SH content in flies significantly depended on dietary yeast $\left(\mathrm{F}_{3,16}=6.52\right.$, $P=0.0043)$ and interaction between yeast concentration in the diet and sex $\left(\mathrm{F}_{3,16}=4.9, P=0.0133\right)$. 


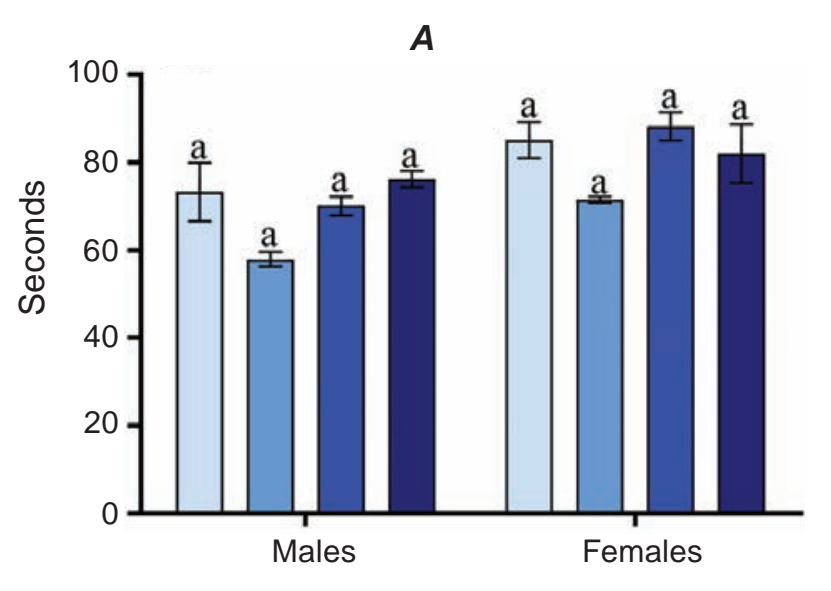

B

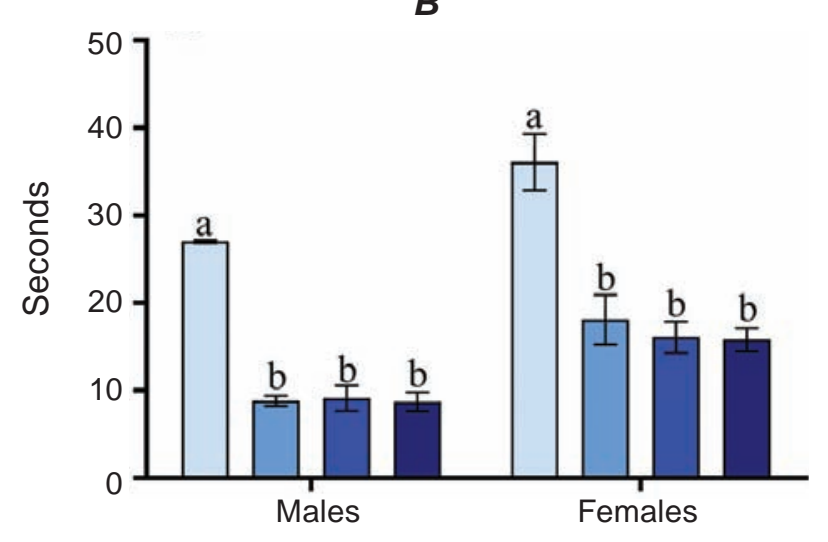

C

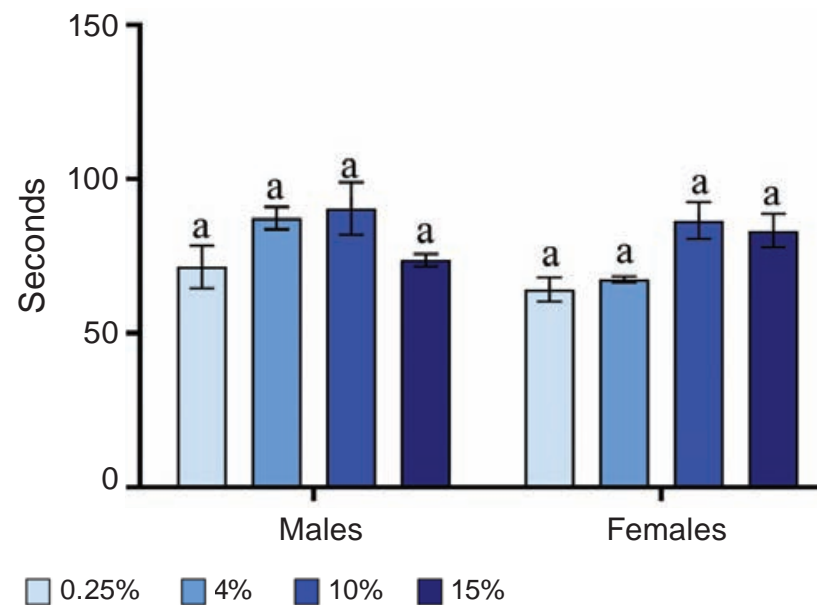

Fig. 2. Sensitivity toward heat $(\boldsymbol{A}, \boldsymbol{B})$ and cold shock (C). $\boldsymbol{A}$ - represents the time required to full fly immobility and is referred as heat paralysis. $\boldsymbol{B}, \boldsymbol{C}-$ represent the time needed for full recovery of locomotion. Points and bars represent mean values and standard error of means. Results are presented as mean \pm SEM of 10 different replicates for each sex/ diet. Values were compared by Tukey's test: $a$ - indicates the highest values among all tested groups; $b-$ significant difference from " $a$ " with $P<0.05$
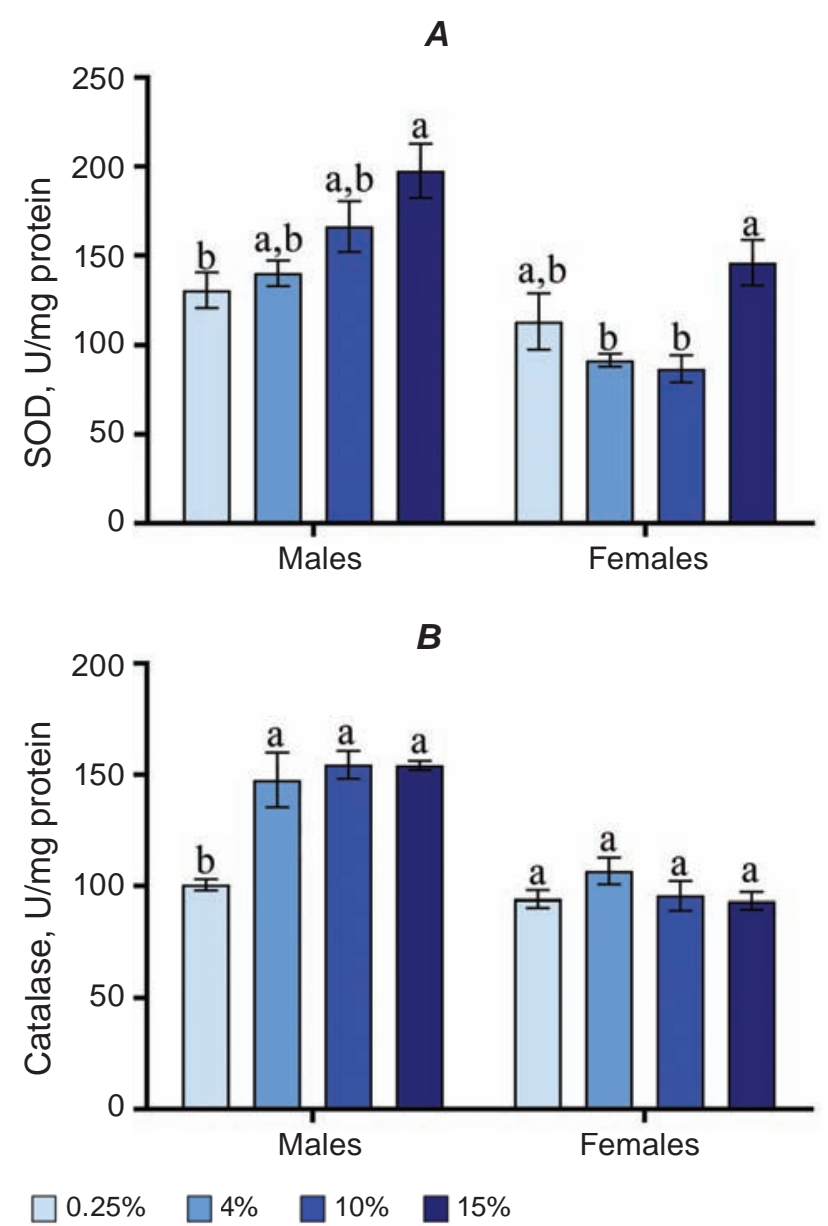

Fig. 3. SOD (A) and catalase (B) activities in flies that consumed diets with different yeast concentrations. Results are shown as mean \pm SEM, $n=4$. Values were compared by Tukey's test: a - indicates the highest mean among all tested groups; $b-$ indicates a significant difference from " $a$ " with $P<0.05$

Approximately 50\% lower level of L-SH was found in males reared on the medium with $0.25 \%$ as compared to $4 \%$ yeast (Fig. 5, B; Tukey's test, $P=0.0301)$. In females, significantly higher L-SH level (by $\sim 30 \%$ ) was observed in flies that consumed medium with $15 \%$ of yeast as compare to all other experimental diets (Fig. 5, $B$; Tukey's test, $P<0.03$ ).

Carbonyl groups can be used as a biological marker for oxidative damage. ROS can attack on side chains of certain amino acids and formed carbonyl groups (Stadtman, 1998). Protein carbonyl groups (PC) level strongly depended on yeast concentration $\left(\mathrm{F}_{3,16}=32.8, P<0.0001\right)$, fly gender $\left(\mathrm{F}_{1,16}=73.1\right.$, $P<0.0001)$ and their interaction $(\mathrm{F} 3,16=8.57$, $P=0.0013$ ). Males fed by diet with $4 \%$ and $15 \%$ of yeast displayed $45 \%$ lower PC content as compared 


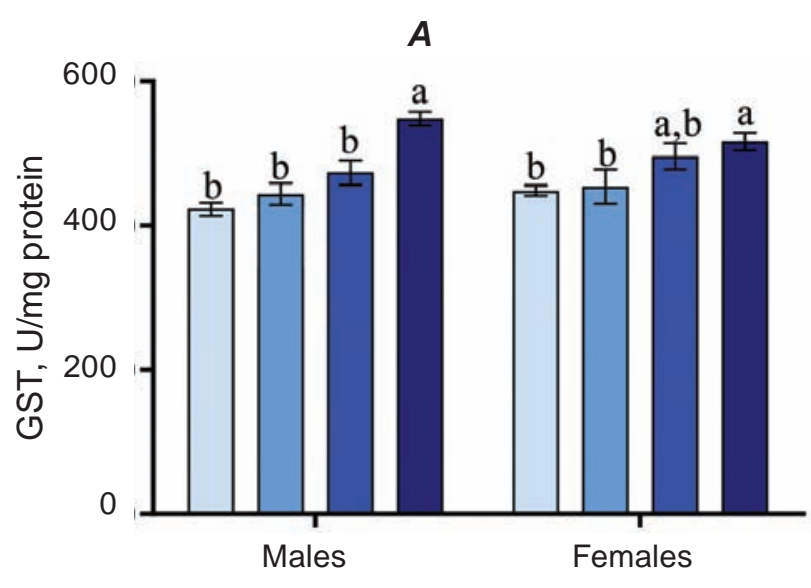

B

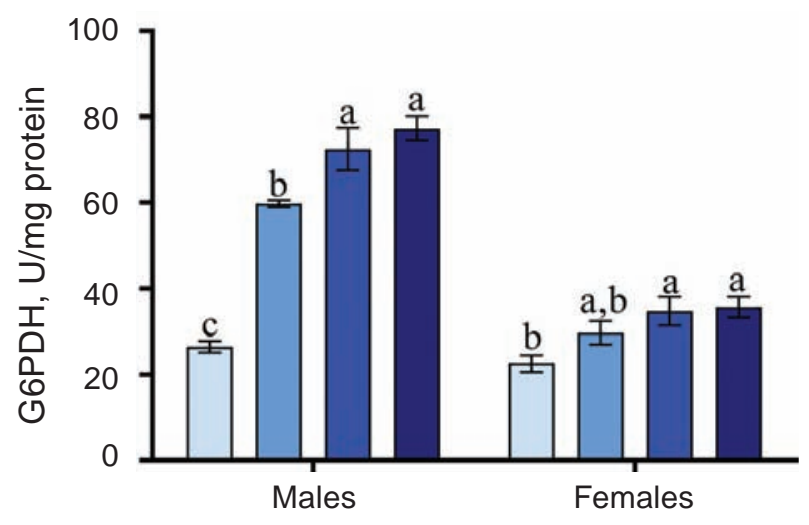

C

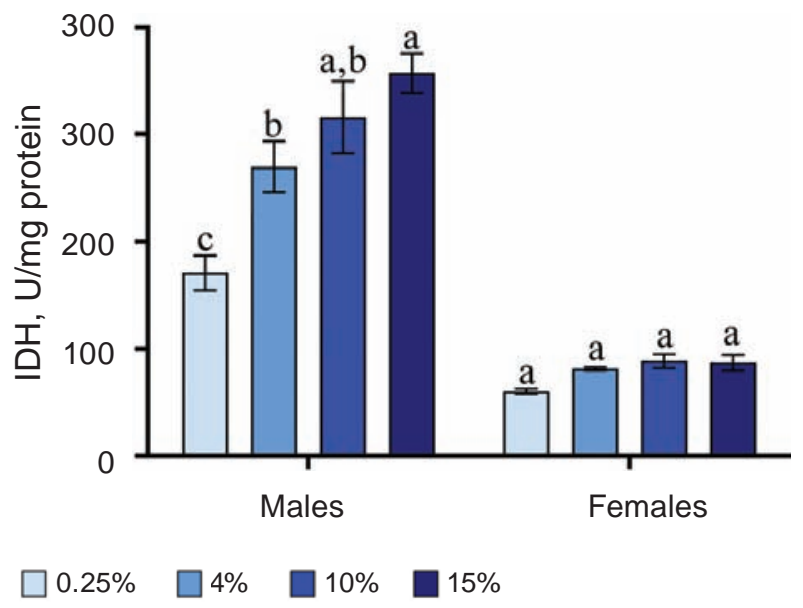

Fig. 4. Activities of glutathione-S-transferases (A), glucose-6-phosphate dehydrogenase (B) and isocitrate dehydrogenase $(\boldsymbol{C})$ in flies that consumed diets with different yeast concentrations. Results are shown as mean \pm SEM, $n=4$. Values were compared by Tukey's test: $a$-indicates the highest mean among all tested groups; $b$ - indicates a significant difference from " $a$ " with $P<0.05$ to $0.25 \%$ (Fig. 5, C; Tukey's test, $P<0.02$ ). Furthermore, lower PC content was detected in males fed by diet with $4 \%$ yeast as compared to $10 \%$ (Fig. 5 , $C$; Tukey's test, $P=0.0245)$. Females fed by diets with $4 \%$ and $10 \%$ yeast concentrations displayed $45 \%$ lower PC level as compared to $0.25 \%$ and $15 \%$ (Figure 5C; Tukey's test $P<0.0004$ ). One of the initial products of free radical attack on lipids are lipid peroxides ( $\mathrm{LOOH})$. LOOH level strongly depended on yeast concentration $\left(\mathrm{F}_{3,16}=9.14, P=0.0009\right)$, fly gender $\left(\mathrm{F}_{1,16}=363, P<0.0001\right)$ and their interaction $\left(\mathrm{F}_{3,16} \stackrel{1,5}{=} 6.51, P=0.0044\right)$. Females fed by diets with 10 and $15 \%$ yeast content displayed 30\% higher LOOH level as compared to 0.25 and $4 \%$ (Fig. 5, D; Tukey's test, $P=0.04)$. The level of $\mathrm{LOOH}$ in males was not affected by dietary yeast (Fig. $5, D$ ).

\section{Discussion}

Macronutrient balance and content of specific nutrients, such as protein, affect life-history traits, including lifespan and fecundity [13]. Numerous pieces of evidence suggest about lifespanextending effect of low-protein diets in rats, mice and Drosophila [8, 9, 24]. Our previous study showed that parental dietary protein-to-carbohydrate ratio $(\mathrm{P}: \mathrm{C})$ influences lifespan, physiological traits and metabolism of not only parental flies but in their offspring [25]. Moreover, we demonstrated that lifespan and metabolism, are affected by dietary sucrose content [26]. We also previously studied that variable sucrose content in the diet of parental generation affects antioxidant capacity in adult offspring Drosophila [27]. Several research investigations have described the impact of dietary restriction on lifespan in Drosophila that mainly depends on the protein content rather than the effect of reduced sugar intake [8]. We thus were interested in the possible existence of protein-dependent effects on resistance to environmental stresses and antioxidant responses. We observed decreased sensitivity to heat-induced stress in flies fed by a protein-restricted diet. One of the potential mechanisms underlying protein-induced heat tolerance is the induction of heat shock proteins under a high-protein diet [28]. In particular, it was suggested that consumption of a protein-rich diet leads to induction of heat shock gene expression. These resulted in increased synthesis of heat shock proteins, mostly Hsp22-28 and Hsp70 [29, 30]. Thus, 
A

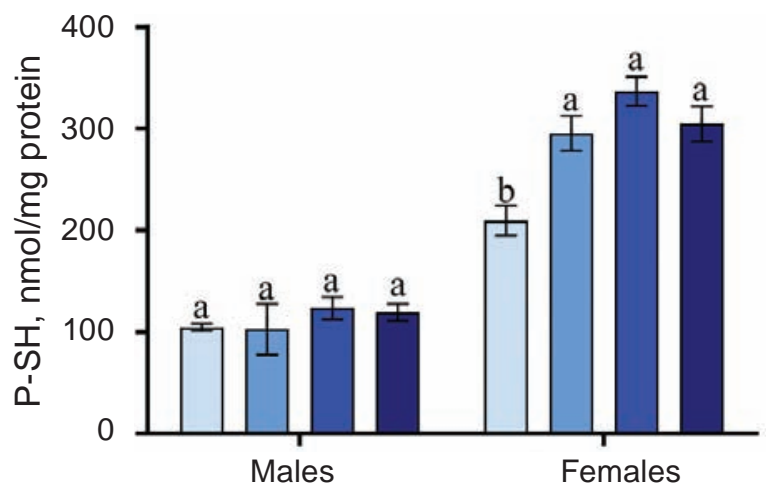

C

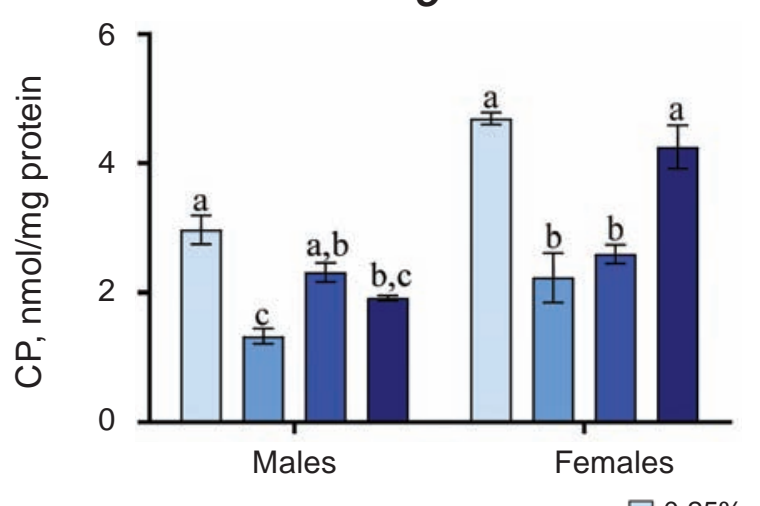

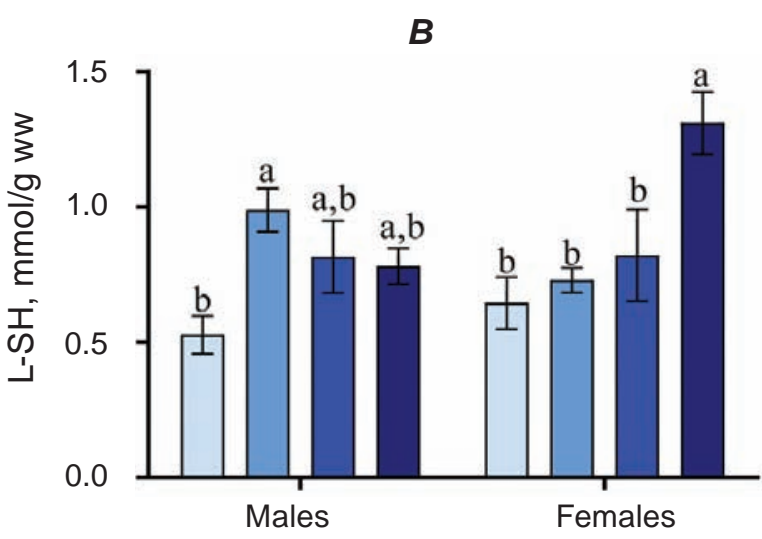

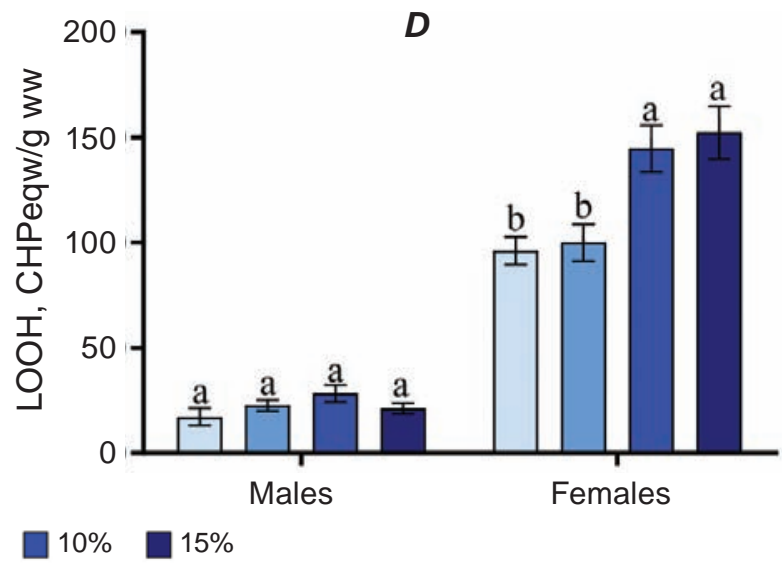

Fig. 5. Levels of protein thiol groups (P-SH) (A), low-molecular-mass thiols ( $L$-SH) (B), protein carbonyls $(P C)(C)$ and lipid peroxides $(\mathrm{LOOH})(\mathbf{D})$ in D. melanogaster fed diets with different yeast concentrations. Results are shown as mean $\pm S E M, n=4$. Values were compared by Tukey's test: $a$-indicates the highest mean among all tested groups; $b$-indicates a significant difference from " $a$ " with $P<0.05$

the high $\mathrm{P}: \mathrm{C}$ ratio in the diet is related to thermal stress resistance.

Consumption of food with the lowest yeast amount (0.25\%) as well as the highest one (15\%) led to decreased lifespan under starvation and oxidative stress (Fig. 1). The mechanism underlying decreased stress tolerance under a low-protein diet is unknown. Drosophila eukaryotic translation initiation factor 4E (eIF4E)-binding protein (d4E-BP) activity becomes critical for survival under dietary restriction and oxidative stress [31]. Poor nutrition causes inhibition of the TOR pathway that leads to 4E-BP unphosphorylation and repression of translation. d4E-BP activity is essential under starvation and oxidative stress conditions [31]. However, high protein content contributes to increased production of ROS that results in decreased stress resistance [32]. ROS overproduction leads to oxidative stress (OS) conditions that is characterized by the imbalance between generation and detoxification of these highly reactive molecules [11]. It is known that higher protein intake may enhance mitochondrial ROS generation and as a result increase the activity of antioxidant enzymes to prevent the development of oxidative stress and restore homeostasis. Indeed, $40 \%$ protein restriction without strong CR also decreases MitROS generation and OS [12]. In the current study, we observed higher activity of first-line antioxidant enzymes, including SOD and catalase in flies fed by a highprotein diet. Hence, our data confirmed that higher dietary yeast concentration enhanced antioxidant defense system in Drosophila.

Increased activity of the second-line antioxidant enzymes, including GST, G6PDH, IDH, may also indicate that high protein content in the diet leads to ROS overproduction, suggesting an adaptive response to protect against cellular OS. Increased activity of the antioxidant enzymes facilitates restoring the balance, which was disturbed due to ROS overproduction under a high-protein diet [33]. 
The most reliable marker of oxidative stress is the level of oxidatively modified molecules [14] including protein- and low-molecular-mass thiolgroup-containing compounds, protein carbonyl and lipid peroxide contents. Our study has shown that a low-protein diet led to a decrease in the level of the OS markers. Some sex-specific differences in the dietary-induced effects on redox homeostasis might be caused by a more extensive biosynthetic metabolism in females related to the need to produce eggs [34]. Furthermore, such gender differences in response to dietary yeast could be caused by differences in physiological processes, nutrient demand and/or sex differences in insulin/IGF-1 signaling (IIS) [35]. The expression of several enzymes important for the cellular defense against oxidative stress is regulated by IIS target - the Drosophila forkhead transcription factor (dFOXO) in the response to nutrients [36]. Studies performed in rodents demonstrated decreased contents of protein carbonyls in rat liver and lipid peroxidation in rat kidneys under protein restriction [37]. Sanz and colleagues demonstrated, that a protein-restricted diet decreased the mitochondrial ROS production and oxidative DNA damage in rats [38].

Evidence confirmed that protein restriction in Drosophila leads to TOR signaling inhibition that, in turn, results in lifespan extension [39]. There was suggested a link between diet, mitochondria, and TOR signaling in the regulation of stress resistance, metabolism and aging [40]. Consequently, TOR signaling could mediate the effect of protein in the diet on metabolism and oxidative homeostasis. Oxidative stress development can also be induced by the amino acid composition of the consumed protein. It is possible that decrease in ROS production (and thus in oxidative damage) was influenced by lower methionine intake [38]. Alternatively, restriction of methionine or of other essential amino acids can be limiting factor for the synthesis of some protein which play role in ROS production by complex I [12].

Conclusions. These results strongly support the idea that dietary yeast content affects certain metabolic and oxidative processes. Our study demonstrated, that the increase in the dietary protein concentration in some cases correlates with increased enzyme activities and is associated with a higher level of oxidative damage markers such as protein thiols, low molecular mass thiols, protein carbonyl and lipid peroxide. Based on the results we can assume that consumption of a high-protein diet could induce oxidative stress in fruit fly. Consequently, oxidative metabolism in $D$. melanogaster strongly correlates with protein intake. The current study provides better mechanistic insight into the aging process. Dietary proteins influence redox signaling processes that are involved in regulating survival.

Conflict of interest. Authors have completed the Unified Conflicts of Interest form at http://ukrbiochemjournal.org/wp-content/uploads/2018/12/ coi_disclosure.pdf and declare no conflict of interest.

\section{ВМІСТ ПРОТЁ̈НІВ У ДІЕТІ ВПЛИВАЕ НА СТІЙКІСТЬ ДО СТРЕСІВ, ОКИСЛЮВАЛЬНІ ПОШКОДЖЕННЯ ТА СТАН СИСТЕМИ АНТИОКСИДАНТНОГО ЗАХИСТУ У DROSOPHILA MELANOGASTER}

\author{
О. М. Стрільбицька ${ }^{1 \bowtie}$, А. В. Заячківська ${ }^{1}$, \\ T. Р. Струтинська ${ }^{1}$ У. В. Семанюк ${ }^{1}$, \\ О. М. Вайсерман ${ }^{2}$, О. В. Лущяак $\kappa^{1,3 凶}$
}
${ }^{1}$ Прикарпатський національний університет імені Василя Стефаника, Івано-Франківськ, Україна; ${ }^{2} Д У$ “Інститут геронтології імені Д. Ф. Чеботарьова НАМН України", Київ;
3Інститут досліджень та розвитку, Івано-Франківськ, Україна; 凶e-mail: olya_b08@ukr.net; oleh.lushchak@pnu.edu.ua

Дослідження останніх років показали, що склад харчового раціону впливає на тривалість життя різних груп модельних організмів. Вміст основних макроелементів, в тому числі й протеїнів та амінокислот, значно позначається на різних фізіологічних процесах та поведінці плодової мушки Drosophila melanogaster. Було важливо з'ясувати ефекти від споживання дієт із різним вмістом дріжджів, що виявляються на стійкості до стресів та функціонуванні системи антиоксидантного захисту дрозофіл. Проаналізовано вплив чотирьох дієт зі сталим вмістом сахарози, які відрізнялися відносним вмістом дріжджів як джерела протеїнів на стійкість до холоду, високих температур, голодування та оксидативного стресу, обумовленого дією менадіону, а також на активність антиоксидантних ензимів та рівень маркерів окисного стресу. Обмеження доступності протеїнів, а також надмірне їх споживання призводили до зниження стійкості до голо- 
дування та оксидативного стресу. Однак вища стійкість до теплового стресу була обумовлена високою концентрацією дріжджів у харчовому раціоні. Споживання їжі, збагаченої протеїнами, спричинювало підвищення активності антиоксидантних ензимів. Підвищений вміст тіольних груп протеїнів та пероксидів ліпідів у відповідь на високі концентрації дріжджів у дієті спостерігався тільки в самок. Дійшли висновку, що дієта, збагачена протеїнами може спричинити оксидативний стрес у дрозофіл.

Кл юч ов і слов в: харчування, дієта, оксидативний стрес, обмін речовин, плодова мушка.

\section{References}

1. Lushchak OV, Gospodaryov DV, Rovenko BM, Glovyak AD, Yurkevych IS, Klyuba VP, Shcherbij MV, Lushchak VI. Balance between macronutrients affects life span and functional senescence in fruit fly Drosophila melanogaster. J Gerontol A Biol Sci Med Sci. 2012; 67(2): 118125.

2. Matzkin LM, Johnson S, Paight C, Bozinovic G, Markow TA. Dietary protein and sugar differentially affect development and metabolic pools in ecologically diverse Drosophila. J Nutr. 2011; 141(6): 1127-1133.

3. Simpson SJ, Raubenheimer D. The geometric analysis of feeding and nutrition: a user's guide. J Insect Physiol. 1995; 41(7): 545-553.

4. Rovenko BM, Kubrak OI, Gospodaryov DV, Perkhulyn NV, Yurkevych IS, Sanz A, Lushchak OV, Lushchak VI. High sucrose consumption promotes obesity whereas its low consumption induces oxidative stress in Drosophila melanogaster. J Insect Physiol. 2015; 79: 42-54.

5. Bayliak MM, Abrat OB, Storey JM, Storey KB, Lushchak VI. Interplay between diet-induced obesity and oxidative stress: Comparison between Drosophila and mammals. Comp Biochem Physiol A Mol Integr Physiol. 2019;228:18-28.

6. Anagnostou C, Dorsch M, Rohlfs M. Influence of dietary yeasts on Drosophila melanogaster life-history traits. Entomol Exp Appl. 2010; 136: 1-11.
7. Davis GR. Essential dietary amino acids for growth of larvae of the yellow mealworm, Tenebrio molitor L. J Nutr. 1975; 105(8): 10711075.

8. Mair W, Piper MDW, Partridge L. Calories do not explain extension of life span by dietary restriction in Drosophila. PLoS Biol. 2005; 3(7): e223.

9. Davis TA, Bales CW, Beauchene RE. Differential effects of dietary caloric and protein restriction in the aging rat. Exp Gerontol. 1983; 18(6): 427435.

10. Fernandes G, Yunis EJ, Good RA. Influence of diet on survival of mice. Proc Natl Acad Sci USA. 1976; 73(4): 1279-1283.

11. Lushchak VI. Free radicals, reactive oxygen species, oxidative stress and its classification. Chem Biol Interact. 2014; 224: 164-175.

12. Pamplona R, Barja G. Mitochondrial oxidative stress, aging and caloric restriction: the protein and methionine connection. Biochim Biophys Acta. 2006; 1757(5-6): 496-508.

13. Lushchak O, Strilbytska O, Piskovatska V, Storey KB, Koliada A, Vaiserman A. The role of the TOR pathway in mediating the link between nutrition and longevity. Mech Ageing Dev. 2017; 164: 127-138.

14. Lushchak O, Strilbytska OM, Yurkevych I, Vaiserman AM, Storey KB. Implications of amino acid sensing and dietary protein to the aging process. Exp Gerontol. 2019; 115: 69-78.

15. Panchaud N, Péli-Gulli MP, De Virgilio C. Amino acid deprivation inhibits TORC1 through a GTPase-activating protein complex for the Rag family GTPase Gtr1. Sci Signal. 2013; 6(277): ra42.

16. Lushchak OV, Gospodaryov DV, Rovenko BM, Yurkevych IS, Perkhulyn NV, Lushchak VI. Specific dietary carbohydrates differentially influence the life span and fecundity of Drosophila melanogaster. J Gerontol A Biol Sci Med Sci. 2014; 69(1): 3-12.

17. Lushchak OV, Rovenko BM, Gospodaryov DV, Lushchak VI. Drosophila melanogaster larvae fed by glucose and fructose demonstrate difference in oxidative stress markers and antioxidant enzymes of adult flies. Comp Biochem Physiol A Mol Integr Physiol. 2011; 160(1): 27-34. 
18. Gibert P, Huey RB. Chill-coma temperature in Drosophila: effects of developmental temperature, latitude, and phylogeny. Physiol Biochem Zool.2001; 74(3): 429-434.

19. Lozinsky OV, Lushchak OV, Storey JM, Storey KB, Lushchak VI. Sodium nitroprusside toxicity in Drosophila melanogaster: delayed pupation, reduced adult emergence, and induced oxidative/nitrosative stress in eclosed flies. Arch Insect Biochem Physiol. 2012; 80(3) 166-185.

20. Gospodaryov DV, Strilbytska OM, Semaniuk UV, Perkhulyn NV, Rovenko BM, Yurkevych IS, Barata AG, Dick TP, Lushchak OV, Jacobs HT. Alternative NADH dehydrogenase extends lifespan and increases resistance to xenobiotics in Drosophila. Biogerontology. 2020; 21(2): 155-171.

21. Lushchak VI, Bagnyukova TV, Husak VV, Luzhna LI, Lushchak OV, Storey KB. Hyperoxia results in transient oxidative stress and an adaptive response by antioxidant enzymes in goldfish tissues. Int J Biochem Cell Biol. 2005; 37(8): 1670-1680.

22. Hermes-Lima M, Willmore WG, Storey KB. Quantification of lipid peroxidation in tissue extracts based on $\mathrm{Fe}(\mathrm{III}) x y l e n o l$ orange complex formation. Free Radic Biol Med. 1995; 19(3): 271-280.

23. Kregel KC. Heat shock proteins: modifying factors in physiological stress responses and acquired thermotolerance. J Appl Physiol. 2002; 92(5): 2177-2186.

24. Min KJ, Tatar M. Drosophila diet restriction in practice: do flies consume fewer nutrients? Mech Ageing Dev. 2006; 127(1): 93-96.

25. Strilbytska O, Velianyk V, Burdyliuk N, Yurkevych IS, Vaiserman A, Storey KB, Pospisilik A, Lushchak O. Parental dietary protein-to-carbohydrate ratio affects offspring lifespan and metabolism in Drosophila. Comp Biochem Physiol A Mol Integr Physiol. 2020; 241: 110622.

26. Strilbytska O, Strutynska T, Semaniuk U, Burdyliyk N, Lushchak O. Dietary sucrose defines lifespan and metabolism in Drosophila. Ukr Biochem J. 2020; 92(5): 97-105.

27. Strilbytska OM, Strutynska TR, Semaniuk UV, Burdyliuk NI, Storey KB, Lushchak OV. Parental dietary sucrose affects metabolic and antioxidant enzyme activities in Drosophila. Entomol Sci. 2021; 24(3): 270-280.
28. Tower J. Heat shock proteins and Drosophila aging. Exp Gerontol. 2011; 46(5): 355-362.

29. Andersen LH, Kristensen TN, Loeschcke V, Toft S, Mayntz D. Protein and carbohydrate composition of larval food affects tolerance to thermal stress and desiccation in adult Drosophila melanogaster. J Insect Physiol. 2010; 56(4): 336-340.

30. Duncan RF. Inhibition of Hsp90 function delays and impairs recovery from heat shock. FEBS $J$. 2005; 272(20): 5244-5256.

31. Tettweiler G, Miron M, Jenkins M, Sonenberg N, Lasko PF. Starvation and oxidative stress resistance in Drosophila are mediated through the eIF4E-binding protein, d4E-BP. Genes Dev. 2005;19(16):1840-1843.

32. Mohanty P, Ghanim H, Hamouda W, Aljada A, Garg R, Dandona P. Both lipid and protein intakes stimulate increased generation of reactive oxygen species by polymorphonuclear leukocytes and mononuclear cells. Am J Clin Nutr. 2002;75(4):767-772.

33. Żebrowska E, Maciejczyk M, ŻendzianPiotrowska M, Zalewska A, Chabowski A. High Protein Diet Induces Oxidative Stress in Rat Cerebral Cortex and Hypothalamus. Int $\mathrm{J} \mathrm{Mol}$ Sci. 2019; 20(7): 1547.

34. Perkhulyn NV, Rovenko BM, Lushchak OV, Storey JM, Storey KB, Lushchak VI. Exposure to sodium molybdate results in mild oxidative stress in Drosophila melanogaster. Redox Rep. 2017; 22(3): 137-146.

35. Magwere T, Chapman T, Partridge L. Sex differences in the effect of dietary restriction on life span and mortality rates in female and male Drosophila melanogaster. J Gerontol A Biol Sci Med Sci. 2004; 59(1): 3-9.

36. Kops GJ, Dansen TB, Polderman PE, Saarloos I, Wirtz KW, Coffer PJ, Huang TT, Bos JL, Medema RH, Burgering BM. Forkhead transcription factor FOXO3a protects quiescent cells from oxidative stress. Nature. 2002; 419(6904): 316-321.

37. Youngman LD, Park JY, Ames BN. Protein oxidation associated with aging is reduced by dietary restriction of protein or calories. Proc Natl Acad Sci USA. 1992; 89(19): 9112-9116.

38. Sanz A, Caro P, Barja G. Protein restriction without strong caloric restriction decreases mitochondrial oxygen radical production and oxidative DNA damage in rat liver. $J$ Bioenerg Biomembr. 2004; 36(6): 545-552. 
39. Katewa SD, Kapahi P. Role of TOR signaling in aging and related biological processes in Drosophila melanogaster. Exp Gerontol. 2011; 46(5): 382-390.
40. Sun X, Wheeler CT, Yolitz J, Laslo M, Alberico T, Sun Y, Song Q, Zou S. A mitochondrial ATP synthase subunit interacts with TOR signaling to modulate protein homeostasis and lifespan in Drosophila. Cell Rep. 2014; 8(6): 1781-1792. 